\title{
Folkloric Use of Solanum surattense Burm. Validates its Pharmacological Activity in Constipation and Diarrhea
}

\author{
Shumaila Andleeb, Muhammad Masood Ahmed*, Fatima Saqib, Musaddique Hussain, Muhammad \\ Hanif and Syed Nisar Hussain Shah
}

\begin{abstract}
Current research was conducted to find out the pharmacological basis of the methanolic extract of Solanum surattense (Ss.ME) for its traditional uses in constipation and diarrhea. In isolated rabbit jejunum preparations, Ss.ME exhibited the spasmogenic effect at lower concentration (0.01-1.0 $\mathrm{mg} / \mathrm{mL}$ ) followed by the spasmolytic effect at next higher concentration $(3-5 \mathrm{mg} / \mathrm{mL})$ with $\mathrm{EC}_{50}$ value of $3.17 \mathrm{mg} / \mathrm{mL}$. $S$. surattense and verapamil (standard $\mathrm{Ca}^{+2}$ channel blocker) caused an inhibition of $\mathrm{K}^{+}(80 \mathrm{mM})$-induced contractions with $\mathrm{EC}_{50}$ value of $0.85 \mathrm{mg} / \mathrm{mL}$ and $0.15 \mathrm{mg} / \mathrm{mL}$ respectively, suggesting $\mathrm{Ca}^{+2}$ channels blockade. Ss.ME caused the right ward shift in $\mathrm{Ca}^{+2}$ concentration response curve, similar to verapamil. Among the fractions, aqueous fraction (Ss.Aq) showed the spasmogenic effect while organic fraction (Ss.DCM) showed spasmolytic effect. It is concluded that methanolic extract of $S$. surattense contains spasmogenic and spasmolytic constituents, which explains its traditional uses in constipation and diarrhea.
\end{abstract}

Keywords - Constipation and diarrhea.

\section{INTRODUCTION}

Solanum surattense Burm. (Solanaceae) is a commonly growing herbaceous weed which is widely distributed throughout the tropical and subtropical regions of South East Asia (Khare, 2007). Photochemical study showed the presence of saponins, alkaloids, tannins, phenols (Shahiladevi et al., 2006), solasonine, solamargine, solasurine (Gawande et al., 1990), torvoside K , torvoside L khasianine (Iida et al., 2005), aculeatiside A andsolamargine (Weissenberg, 2001). During the recent studies, following steroidal alkaloid saponins and steroidal saponins such as (22R, 25R)-16 $\beta$-H-22 $\alpha$-N-spirosol-3 $\beta$-ol-5-ene-3-O- $\alpha$-L-rhamnopyra nosyl-(1-2)-[ $\alpha$-L-rhamnopyranosyl-(1-4)]- $\beta$-D-glucopyranosid e; $\quad(22 \mathrm{R}, \quad 23 \mathrm{~S}, \quad 25 \mathrm{R})-3 \beta, \quad 6 \alpha$, 23 -trihydroxy-5 $\alpha$-spirostane-6-O- $\beta$-Dxylopyranosyl-(1-3)-O- $\beta$ D-quinovopyranoside; $\quad(22 \mathrm{R}, \quad 23 \mathrm{~S}, \quad 25 \mathrm{~S})-3 \beta, \quad 6 \alpha$, 23 -trihydroxy- $5 \alpha$-spirostane-6-O- $\beta$-Dxylopyranosyl-(1-3)-O- $\beta$ -

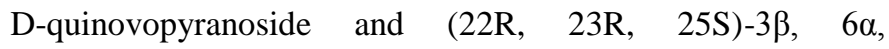
23 -trihydroxy-5 $\alpha$-spirostane6-O- $\beta$-Dxylopyranosyl-(1-3)-O- $\beta$ -

D-quinovopyranoside have also been isolated (Lu et al., 2011).

In the traditional system of medicines, S. surattense is used as colic, laxative, anorexia, carminative, appetizer, and

Dr Muhammad Masood Ahmed, Faculty of Pharmacy, Bahauddin Zakariya University, Multan, Pakistan.

Shumaila Andleeb, Fatima Saqib, Musaddique Hussain, Muhammad Hanif and Syed Nisar Hussain Shah, Faculty of Pharmacy, Bahauddin Zakariya University, Multan, Pakistan. expectorant as well as used to treat constipation, cough, asthma, bronchitis, cardiac disorders and hypertension (Kiritikar and Basu, 1987; Khare, 2007). Hypoglycemic potential of the fruit was studied in diabetic rats (Gupta et al., 2005). Scientific investigation revealed the hypoglycemic potential in diabetic rats (Kar et al., 2006), strong antibacterial activity against Pseudomonas aeruginosa (Ghani et al., 2010), wound healing activity (Kumar et al., 2010), physicochemical activity (Meena et al., 2010) and antioxidant potential (Priyadarsini et al., 2010).

Although S. surattense has traditionally been used to treat GIT motility disorders, but no pharmacological data are available in order to validate such traditional uses. The purpose of present study was to investigate its therapeutic potential and possible mechanism of action which may authenticate the traditional uses of the plant in constipation and diarrhea.

\section{MATERIALS AND METHODS}

Plant collection and identification: Whole plant of Solanum surattense was collected from Kot Addu, Pakistan, in September 2012, and identified by Prof. Dr. Altaf Ahmad Dasti (Taxanomist), at the Institute of Pure and Applied Biology, Bahauddin Zakariya University, Multan (Pakistan) with voucher number STW. Flora, 644.

Extraction and fractionation: Debris and adulterants free air dried whole plants of S. surattense were grinded into coarse powder (\#40) by herbal grinder and subjected to extraction by triple maceration process with $\mathrm{MeOH}$ at room temperature, to dark brown thick syrup consistency; named Ss.ME, which was subsequently lyophilized to remove moisture contents with approximate yield of $19.1 \%$. The extract was partitioned between DCM (Ss.DCM) and aqueous (Ss.Aq) portion, containing organic and water soluble constituents respectively (Hussain et al., 2014; Hussain et al., 2015a).

Drugs and chemicals: Acetylcholine, atropine sulfate, carbachol, dicyclomine and verapamil hydrochloride were purchased from Sigma Chemicals Co. St Louis, MO, USA, while all other chemicals used were of the highest analytical grade. All the dilutions were prepared by dissolving the drugs in freshly prepared normal saline $(0.9 \% \mathrm{NaCl})$ on the day of experiment.

Animals and housing conditions: Animals ( $(\hat{\delta} /$ 우) including, mice (Swiss albino 32-50 g) and rabbits (0.9-1.5 kg, age limit between 6 to 8 months) were provided with tap water ad libitum and standard diet. All the animals were housed at animal house $\left(25-28^{\circ} \mathrm{C}\right)$ of Faculty of Pharmacy, Bahauddin Zakariya 
University, Multan. Before the commencement of experiments, food was withdrawn from all animals but had free access to water. The rabbits were dissected to remove jejunum for in vitro experiments. All the experiments were performed by following ruling of Institute of Laboratory Animal Resources, Commission on Life Sciences (National Research Council, 1996).

Acute toxicity test: Acute toxicity test was performed by using 2, 4 and $6 \mathrm{~g} / \mathrm{kg}$ of S. surattense, as previously described (Hussain et al., 2014).

Spasmogenic and spasmolytic activity on isolated rabbit jejunum preparation: The spasmogenic and/or spasmolytic activity of freshly prepared plant extract was tested on isolated rabbit jejunum preparations as previously described (Hussain et al., 2014; Hussain et al., 2015b). A preload of $1 \mathrm{~g}$ was applied to isolated rabbit jejunum segments $(2-3 \mathrm{~cm})$ dangled in tissue baths containing Tyrode's solution, aerated with carbogen $\left(37^{\circ} \mathrm{C}\right)$. Stabilized rabbit jejunum preparations demonstrate impulsive rhythmic contractions and were tested for spasmogenic effect without application of an agonist (Arshad et al., 2012; Janbaz et al., 2014a). The contractile effect of the plant material was assessed as the percent of the maximum effect produced by the control drug, acetylcholine $(1.0 \mu \mathrm{M})$.

Determination of $\mathrm{Ca}+2$ channel blocking activity: To assess whether the sapsmolytic activity of the plant extract was through blockade calcium channel ( $\mathrm{CCB}$ ), $\mathrm{K}+$ as high conc. of $\mathrm{KCl}$, i.e., $\mathrm{K}+(80 \mathrm{mM})$, was added to tissue bath for the depolarization of jejunum preparation as previously described (Janbaz et al., 2014a), which produced as sustained contraction. Freshly prepared plant extracts were applied to sustained contractions in a cumulative manner to obtain concentration-dependent inhibitory response (Van-Rossum, 1963; Janbaz et al., 2014b). The observed relaxant effect of the plant extract on $\mathrm{K}+(80$ $\mathrm{mM}$ )-induced contraction was expressed as percent of the control response mediated by $\mathrm{K}+$.

For the confirm of calcium channel blocking activity of plant extract,the isolated rabbit jejunum preparations were allowed to stabilize in normal Tyrode's solution, which were subsequently replaced with $\mathrm{Ca}+2$-free Tyrode's solution to which EDTA $(0.1$ $\mathrm{mM}$ ) was added for $30 \mathrm{~min}$, in order to remove calcium from the jejunum preparations (Gilani et al., 2005). Previously added solution was further replaced with $\mathrm{K}+$-rich and $\mathrm{Ca}+2$-free Tyrode's solution.

Subsequent to an incubation period of $30 \mathrm{~min}$, control calcium dose-response curves (CRCs) of calcium were prepared by applying the $\mathrm{Ca}+2$ concentrations in cumulative manners to the tissue bath. On achievement of the super-imposable control calcium dose-response curves (usually after two cycles), the tissues were then washed and pretreated with the plant extract for $60 \mathrm{~min}$ to test a possible CCB effect. The concentration response curves for $\mathrm{Ca}+2$ were developed in the presence of different concentrations of the plant extract and compared to the control curves, to assess a possible $\mathrm{Ca}+2$ channel blocking effect (Bolton, 1979).
Data analysis and statistics: The data is expressed as mean \pm S.E.M and median effective concentration (EC50) values are given with $95 \%$ confidence intervals $(95 \% \mathrm{CI})$ and the logarithmic dose response curves of different treatments were then plotted using computer software "Graph pad Prism" version 6.Concentration-response curves were analyzed by nonlinear regression sigmoidal response curve (variable slope). Student t- test was applied for assessment of the observations. P $<0.01$ was considered statistically significant.

\section{RESULTS}

Acute toxicity of S. surattense: Acute toxicity of S. surattense was tested at different doses $(2,4$ and $6 \mathrm{~g} / \mathrm{kg})$; there was zero mortality and no change in animal behavior up to the dose as high as $6 \mathrm{~g} / \mathrm{kg}$ which is higher than the normal therapeutic dose, suggesting that the $\mathrm{S}$. Acute toxicity of $\mathrm{S}$. surattense: Acute toxicity of $\mathrm{S}$. surattense was tested at different doses (2, 4 and 6 $\mathrm{g} / \mathrm{kg}$ ); there was zero mortality and no change in animal behavior up to the dose as high as $6 \mathrm{~g} / \mathrm{kg}$ which is higher than the normal therapeutic dose, suggesting that the S. surattense is safe.

Spasmogenic and spasmolytic effect of $S$. surattense on rabbit jejunum preparations: Freshly prepared methanolic extract of S. surattense (Ss.ME) showed the appreciable spasmogenic response on spontaneously contracting isolated rabbit jejunum preparations at lower concentration of 0.01-1.0 $\mathrm{mg} / \mathrm{mL}$ which did not sustained and was subsequently followed by spasmolytic effect at the next higher dose $(3-5 \mathrm{mg} / \mathrm{mL})$ with EC50value of $3.17 \mathrm{mg} / \mathrm{mL}$ (95\% CI: 2.32-3.95, n=3) (Figure 1 and 2). The observed contractile responses to Ss.ME was expressed as percentage of the maximal response to acetylcholine $(0.3 \mu \mathrm{M})$, i.e. $25.70 \pm 0.7,36.07 \pm 1.7,49.60 \pm$ $2.7,62.13 \pm 3.2$ and $18.33 \pm 2.1$ (mean \pm S.E.M., $n=3$ ), at the dose range of $0.01,0.03,0.1,0.3$ and $1.0 \mathrm{mg} / \mathrm{mL}$ respectively (Figure 3). Pretreatment of jejunum preparation with atropine $(0.1 \mu \mathrm{M})$ completely masked the spasmogenic effect while the spasmolytic effect was noticed with EC50value of $0.28 \mathrm{mg} / \mathrm{mL}$ (CI 95\%:0.11-0.57, n=3) (Figure 1 and 2).

Ss.ME caused the concentration-dependent relaxation of $\mathrm{K}+(80 \mathrm{mM})$-induced contractions with EC50value of 0.85 $\mathrm{mg} / \mathrm{mL}$ (95\% CI: 0.29-1.40, $\mathrm{n}=3$ ), while verapamil used as a reference standard produced the marked inhibition of $\mathrm{K}+(80$ $\mathrm{mM}$ )-induced contractions, with EC50value of $0.15 \mathrm{mg} / \mathrm{mL}$ (95\% CI: 0.05-0.31, n=3) (Figure 4). Ss.ME caused a rightward shift in the $\mathrm{Ca}+2$-concentration response curves at the dose range of $0.1-1.0 \mathrm{mg} / \mathrm{mL}(\mathrm{n}=3)$, constructed in the $\mathrm{Ca}+2$-free and $\mathrm{K}+$ rich medium, like that caused by verapamil at $0.1-1.0 \mu \mathrm{M}$ $(\mathrm{n}=3)$, (Figure 4).

Activity-directed fractionation showed that application of aqueous fraction of S. surattense (Ss.Aq) to the isolated rabbit jejunum preparation caused the spasmogenic effect at dose of 0.3-3.0 $\mathrm{mg} / \mathrm{mL}$ while pretreatment of the tissue with atropine $(0.1 \mu \mathrm{M})$ abolish the spasmogenic effect (Figure $6 \mathrm{~A}$ and B). Whereas, organic fraction of $\mathrm{S}$. surattense (Ss.DCM) antagonized the spontaneous and $\mathrm{K}+(80 \mathrm{mM})$-induced 
contraction with EC50 values of $0.42 \mathrm{mg} / \mathrm{mL}(95 \% \mathrm{CI}$ : $0.18-0.83: \mathrm{n}=3)$ and $0.08 \mathrm{mg} / \mathrm{ml}(95 \% \mathrm{CI}: 0.02-0.32, \mathrm{n}=3)$ respectively (Figure 6C, 7 and 8).
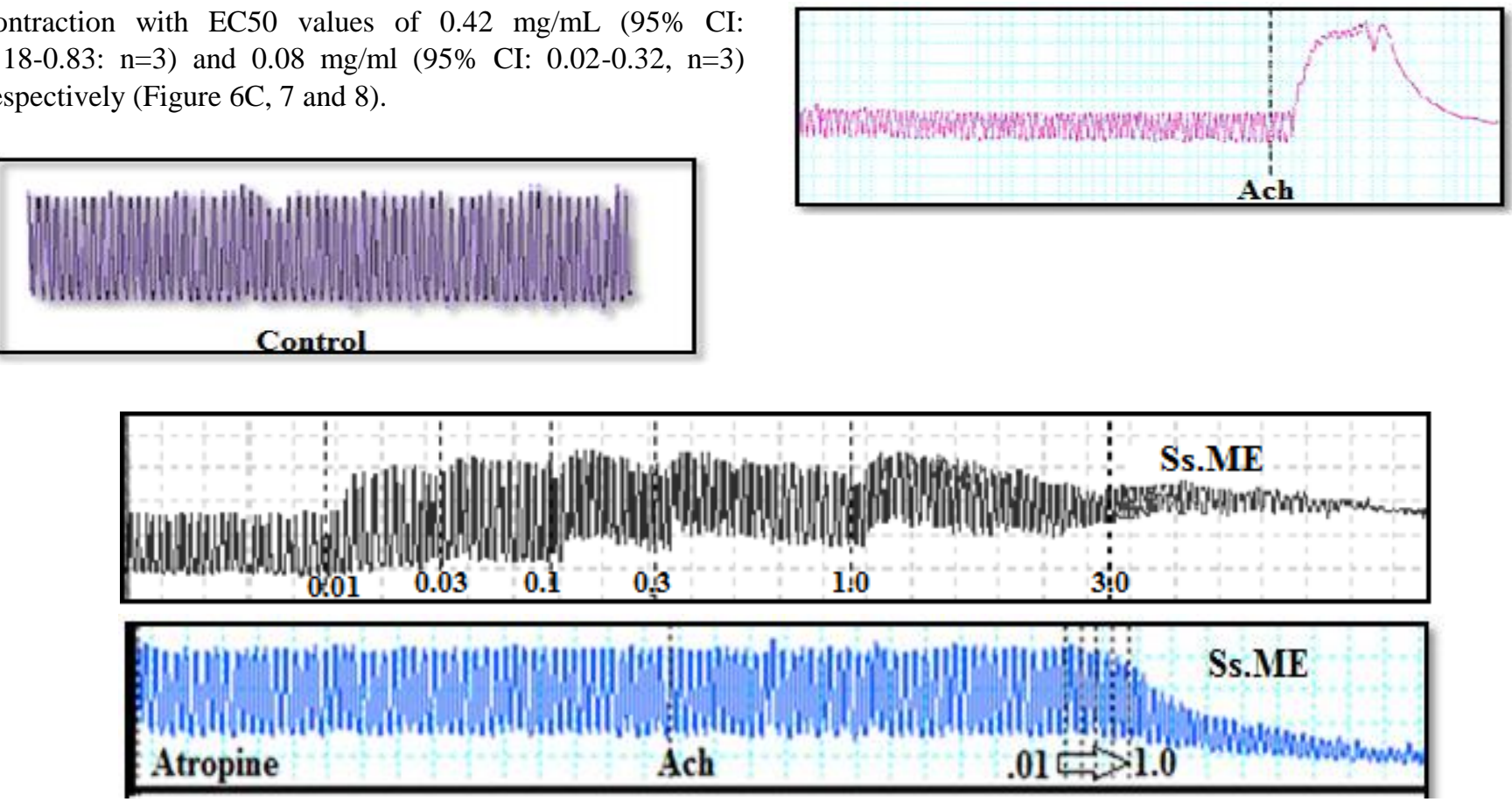

Fig. 1:Tracing showing the spasmolytic effect of the methanolic extract of S. surattense (Ss.ME) in comparison to acetylcholine in the absence and presence of atropine $(0.1 \mu \mathrm{M})$ on spontaneously contracting isolated rabbit jejunum preparation

Figure 1:Tracing showing the spasmolytic effect of the methanolic extract of S. surattense (Ss.ME) in comparison to acetylcholine in the absence and presence of atropine $(0.1 \mu \mathrm{M})$ on spontaneously contracting isolated rabbit jejunum preparation.

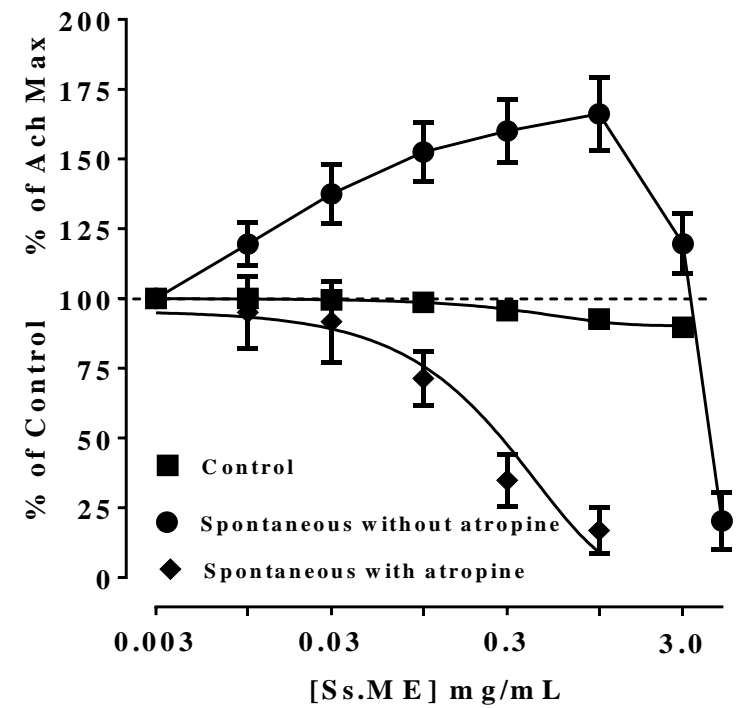

Figure 2: Concentration-response curves, showing the effect of methanolic extract of S. surattense (Ss.ME) in the absence and presence of atropine $(0.1 \mu \mathrm{M})$ on spontaneously contracting isolated rabbit jejunum preparation. The spasmogenic responses are expressed as percent of acetylcholine maximum (Ach Max) (values are expressed as mean \pm S.E.M, $n=3$ ).

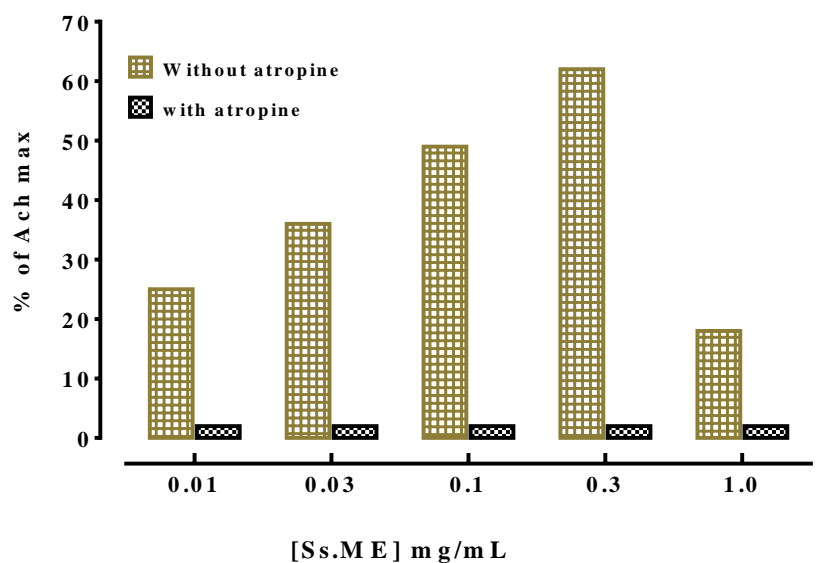

Figure 3: Bar diagram showing the effect of the methanolic extract of S. surattense (Ss.ME) in comparison to the acetylcholine maximum response in the presence and absence of atropine on isolated rabbit jejunum preparation (values are expressed as mean \pm S.E.M.). 


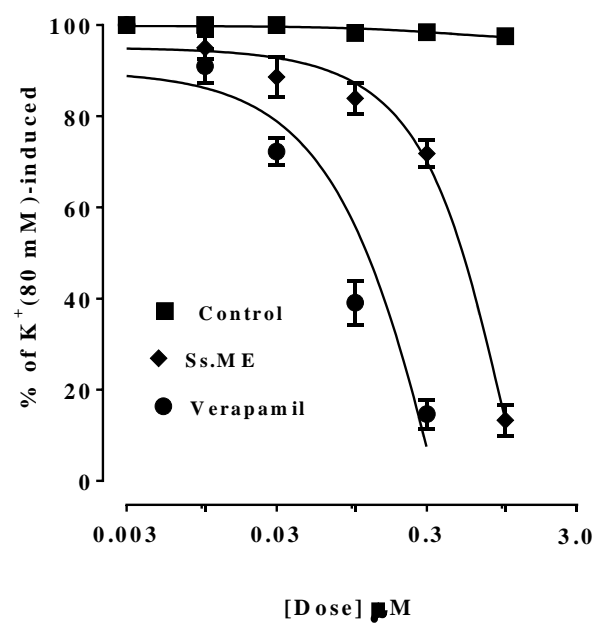

Figure 4: Concentration-dependent inhibitory effect of the methanolic extract of S. surattense (Ss.ME) and verapamil against $\mathrm{K}+(80 \mathrm{mM})$-induced contractions in isolated rabbit jejunum preparations (values are expressed as mean \pm S.E.M., $\mathrm{n}=3$ ).

(A)

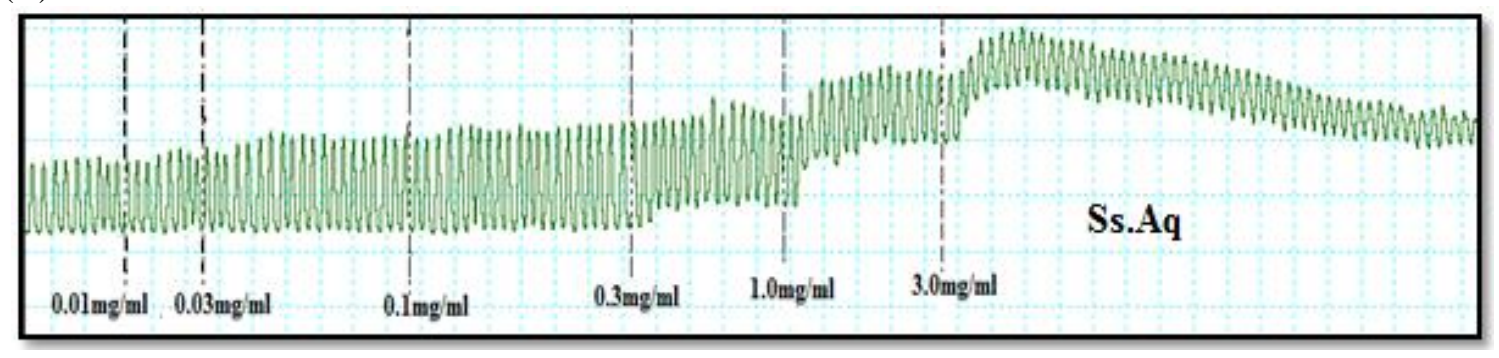

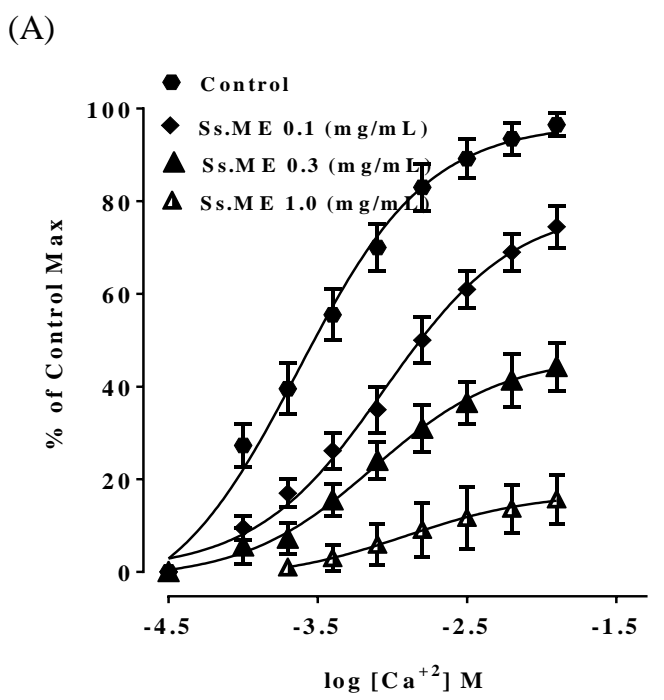

(B)

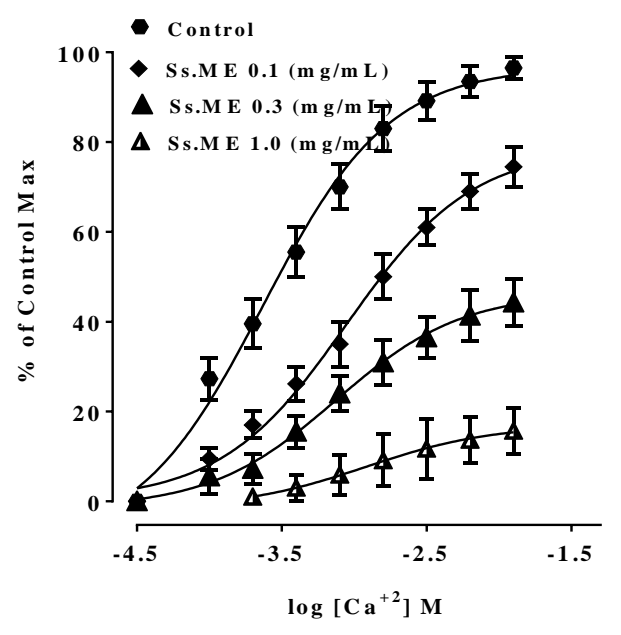

Figure 5: Concentration-response curves of $\mathrm{Ca}+2 \mathrm{in}$ the absence and presence of different concentrations of (A) methanolic extract of S. surattense and (B) verapamil in isolated rabbit jejunum preparations (values are expressed as mean \pm S.E.M., $n=3$ ). 
(B)

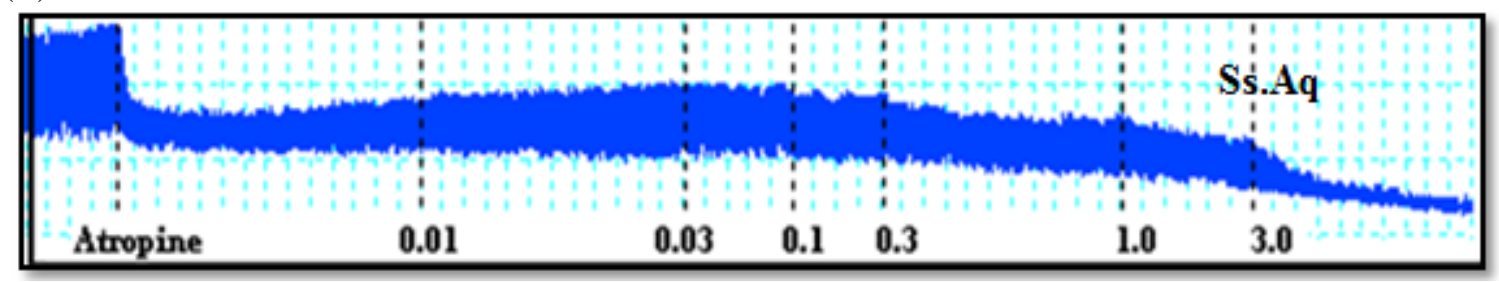

(C)

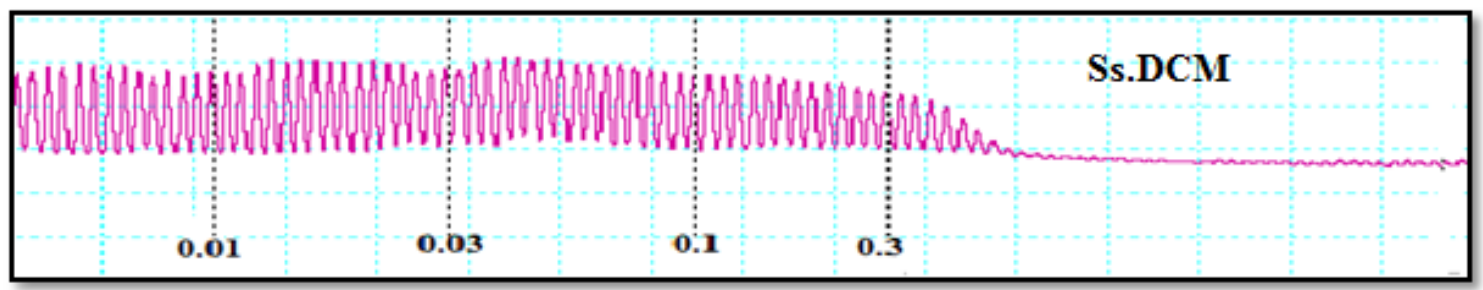

Figure 6: Tracing showing the (A) spasmogenic effect of the aqueous fraction of $\mathrm{S}$. surattense (Ss.Aq) (B) spasmolytic effect (on atropinized tissue) of aqueous fraction of S. surattense, and (C) spasmolytic effect of the organic fraction of S. surattense (Ss.DCM) on spontaneously contracting isolated rabbit jejunum preparations.
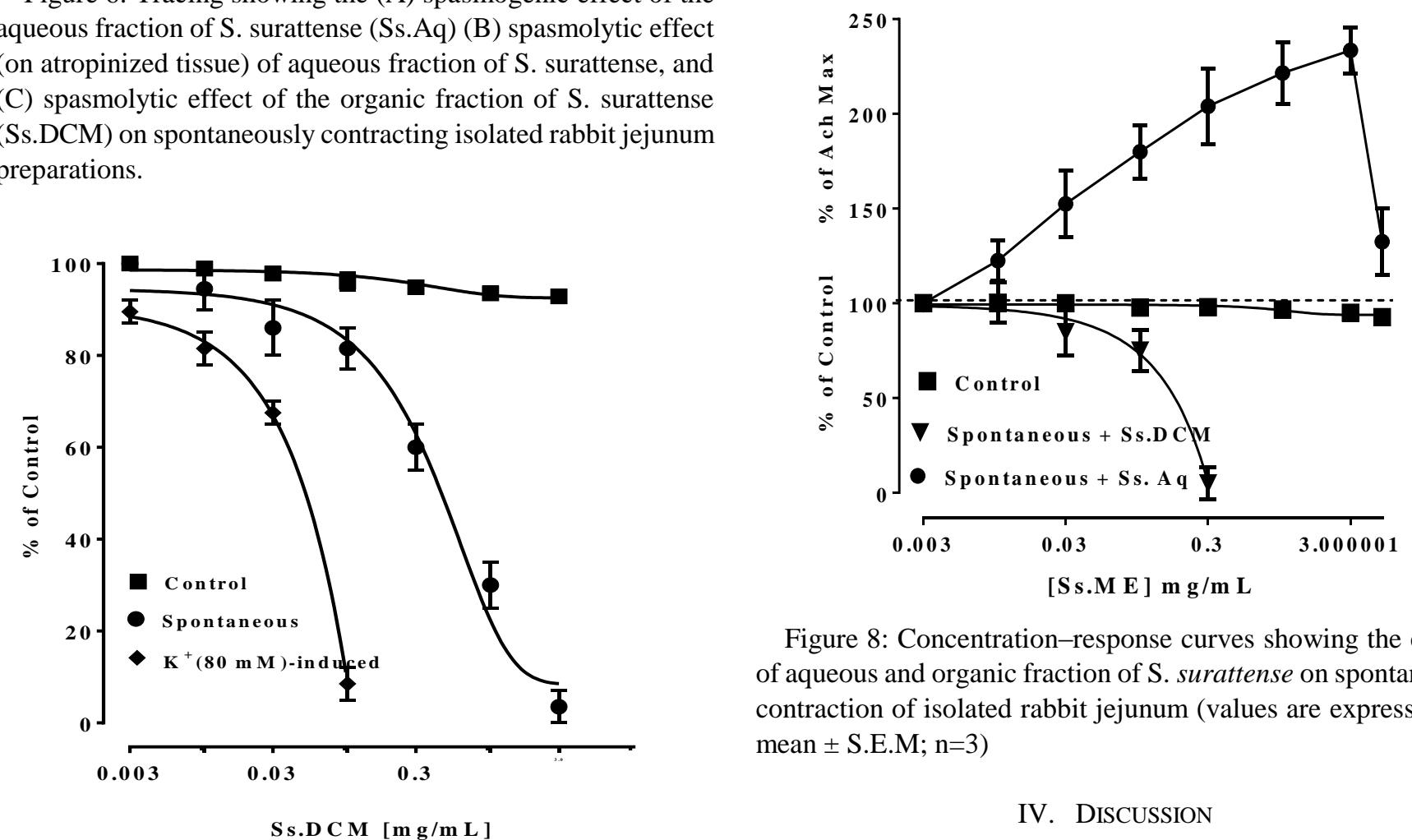

Figure 8: Concentration-response curves showing the effect of aqueous and organic fraction of S. surattense on spontaneous contraction of isolated rabbit jejunum (values are expressed as mean \pm S.E.M; $n=3$ )

\section{DISCUSSION}

Figure 7: Concentration-response curves showing the effect of organic fraction of S. surattense (Ss.DCM) on spontaneous and $\mathrm{K}+(80 \mathrm{mM})$-induced contracted isolated rabbit jejunum(values are expressed as mean \pm S.E.M; $n=3$ ). 
muscarinic receptors while atropine antagonizes all muscarinic receptors subtypes (Brown et al., 1996). Cholinergic agents are known to increase the secretory and motor activity of gut (Pappano, 2007). Noticed contractile response of the methanolic extract, same as acetylcholine, may elaborate the traditional use of $\mathrm{S}$. surattense in constipation. However, the co-existence of other mechanisms cannot be excluded. The spasmogenic effect was followed by the spasmolytic effect at next higher doses of the methanolic extract, indicating the co-existence of spasmogenic and spasmolytic constituent(s), which is probably meant by the nature not to allow the spasmogenic effect going beyond the constipation, particularly at higher doses (Hussain et al., 2015c).

It had been previously noticed that the spasmolytic constituents mediate their response through blockade of $\mathrm{Ca}+2$ channels (CCB) (Gilani et al., 2005). A high concentration of $\mathrm{K}+(80 \mathrm{mM})$ was added to spontaneously contracting rabbit jejunum preparations, to assess whether the spasmolytic effect of S. surattense is mediated through $\mathrm{CCB}$, which resulted in sustained contraction of jejunum. Addition of Ss.ME to high $\mathrm{K}+(80 \mathrm{mM})$-induced contraction in a cumulative manners, resulted in relaxation of sustained contraction of jejunum , similar to verapamil. High $\mathrm{K}+(80 \mathrm{mM})$ is known to cause smooth muscles contraction either through opening of voltage-dependent slow $\mathrm{Ca}+2$ channels or through allowing the influx of extracellular $\mathrm{Ca}+2$ (Godfraind et al., 1986). Thus inhibitory effect of the methanolic extract against high $\mathrm{K}+(80$ $\mathrm{mM}$ )-induced contraction can be visualized as the calcium channels blockade. The presence of $\mathrm{Ca}+2$ antagonistic response in S. surattense was confirmed when it caused a rightward shift in the $\mathrm{Ca}+2$ concentration-response curves, constructed in $\mathrm{Ca}+2$ free and $\mathrm{K}+$ rich medium, similarly as verapamil (Hussain et al., 2015c). Interestingly calcium channels blockade are known to be valuable as antispasmodic and anti-diarrheal (Brunton, 1996).

In order to separate the constituents responsible for the spasmogenic and spasmolytic activities, activity directed fractionation was carried out which revealed that spasmolytic effect was separated in organic fraction (DCM) which cause the inhibition of spontaneous as well as $\mathrm{K}+(80 \mathrm{mM})$-induced contraction. The spasmogenic effect was found to be exhibit in the aqueous fraction, followed by the relaxation at higher concentration, while pretreatment of the tissue with atropine $(0.1 \mu \mathrm{M})$ abolish the spasmogenic effect, conforming the cholinergic effect. The aqueous fraction could not be tested against $\mathrm{K}+(80 \mathrm{mM})$-induced contraction due to limited supplies. The aqueous fraction was found to possess a combination of weak spasmolytic and spasmogenic activities.

\section{CONCLUSION}

From the present study it is inferred that methanolic extract of S. surattense contains spasmogenic constituents which are separated in organic fraction. Spasmogenic activity of S. surattense was similar to acetylcholine while spasmolytic effect resembled calcium channel blockade. Moreover, these results authenticate the traditional use of S. surattense in constipation and diarrhea.

\section{REFERENCES}

[1] Arshad U, Janbaz KH, Bashir S, Rehman NU, Mehmood MH, Gilani AH. Ethnopharmacological studies on Chrozophora prostrata in perspective of its folkloric reputation as purgative. Bangldesh J Pharmacol. 2012; 7: $243-48$. https://doi.org/10.3329/bjp.v7i4.12351

[2] Bolton TB. Mechanisms of action of transmitters and other substances on smooth muscle. Physiol Rev. 1979; 59: 606-718. https://doi.org/10.1152/physrev.1979.59.3.606

[3] Brown JH, Taylor P. Muscarinic receptor agonists and antagonists. In: Gilman AG, Hardman JG, Limbird LE, Molinoff PB, Ruddon RW. (Eds.) The Pharmacological Basis of Therapeutics. New York: McGraw-Hill, 1996, p 141-59.

[4] Brunton LL. Agents affecting gastrointestinal water flux and motility; emesis and antiemetics; bile acids and pancreatic enzymes. In: Gilman AG, Hardman JG, Limbird LE, Molinoff PB, Ruddon RW (Eds.), Goodman \& Gilman's The Pharmacological Basis of Therapeutics, The McGraw-Hill, New York, 1996, p 917-36.

[5] Gawande A, Wankhade S, Shankhapal KV, Shinde GB. Isolation, purification and characterization of solasodine-A steroidal alkaloid from Solanum surattense berries. Indian Drugs. 1990; 28: 149-50.

[6] Ghani MS, Farooq MU, Khan MTJ. Phytochemical investigations and evaluation of antibacterial and irritant potential of different extracts of whole plant of Solanum xanthocarpum Schrad and Wendl. J Chin Chem Soc. 2010; 57: 1257-62.

[7] Gilani AH, Bashir S, Janbaz KH, Shah AJ. Presence of cholinergic and calcium channel blocking activities explains the traditional use of Hibiscus rosasinensis in constipation and diarrhea. J Ethnopharmacol. 2005; 102: 289-94.

https://doi.org/10.1016/j.jep.2005.07.023

[8] Gilani AH, Shah AJ, Ghayur MN, Majeed K. Pharmacological basis for the use of Turmeric in gastrointestinal and respiratory disorders. Life Sci. 2005; 76: 13089-105.

https://doi.org/10.1016/j.lfs.2004.12.021

[9] Godfraind T, Miller R, Wibo M. Calcium antagonism and calcium entry blockade. Pharmacol Rev. 1986; 38: 321-26.

[10] Gupta S, Mal M, Bhattacharya P. Evaluation of hyperglycemia potential of Solanum xanthocarpum fruit in normal and streptozotocin induced diabetic rats. Eur Bull Drug Res. 2005; 13: 55.

[11] Hussain M, Raza SM, Janbaz KH. Pharmacological basis for the folkloric uses of Buxus wallichiana Baill. (Buxaceae) in gastrointestinal, respiratory and vascular disorders. Bangladesh J Pharmacol. 2015b; 10: 260-266. https://doi.org/10.3329/bjp.v10i2.22285

[12] Hussain M, Raza SM, Janbaz KH. Pharmacological evaluation and validation for the folkloric use of Oligochaeta ramose (Roxb.) in constipation and diarrhea. Bangladesh J Pharmacol. 2014; 9: 617-23. https://doi.org/10.3329/bjp.v9i4.20566

[13] Hussain M, Raza SM, Khan MRU, Majeed A. Assessment of antiemetic potential of crude extract of Vigna trilobata (Linn.) against different emetogenic stimuli; an in vivo study. Indo Am J Pharmaceut Res. 2015a; 5: 1588-93.

[14] Hussain M, Raza SM, Janbaz KH. Pharmacologically mechanistic basis for the traditional uses of Rumex acetosa (Linn) in gut motility disorders and emesis. Bangladesh J Pharmacol. 2015c; 10: 548-554. https://doi.org/10.3329/bjp.v10i3.23406

[15] Iida Y, Yanai Y, Ono M, Ikeda T, Nohara T. Three unusual 22-b-O-23hydroxy-(5a)-spirostanol glycosides from the fruits of Solanum torvum. Chem. Pharm. Bull. 2005; 53: 1122-25. https://doi.org/10.1248/cpb.53.1122

[16] Janbaz KH, Qayyum A, Saqib F, Imran I, Zia-Ul-Haq M, De Feo V. Bronchodilator, vasodilator and spasmolytic activities of Cymbopogon martini. J physio pharmacol. 2014b; 65: 859-66.

[17] Janbaz KH, Shabbir A, Mehmood MH, Gilani AH. Pharmacological basis for the medicinal use of Rhus coriaria in hyperactive gut disorders. Bangldesh J Pharmacol. 2014a; 9: 636-44. https://doi.org/10.3329/bjp.v9i4.20879 
[18] Kar DM, Maharana L, Pattnaik S, Dash GK. Studies on hypoglycaemic activity of Solanum xanthocarpum fruit extract in rats. J Ethnopharmacol. 2006; 108: 251-56. https://doi.org/10.1016/j.jep.2006.05.016

[19] Khare CP. Indian Medicinal Plants, An Illustrated Dictionary. Springer, Berlin/ Heidelberg, New Delhi, India, 2007, p 615. https://doi.org/10.1007/978-0-387-70638-2

[20] Kiritikar KR, Basu BD. Indian Medicinal plants, Vol III, Dehradun, India, International Book Distributor, 1987.

[21] Kumar N, Prakash D, Kumar P. Wound healing activity of Solanum xanthocarpum Schrad. \&Wendl. fruits. Indian J Nat Prod Resour. 2010; 1: 470-75.

[22] Lu Y, Luo J, Kong L. Steroidal alkaloid saponins and steroidal saponins from Solanum surattense. Phytochemistry. 2011; 72: 668-73. https://doi.org/10.1016/j.phytochem.2011.01.028

[23] Meena AK, Rao MM, Kandale A, Sharma K, Singh U, Yadav A. Evaluation of physicochemical and standardisation parameters of Solanum xanthocarpum Schrad. \& Wendl. Int J Chem Anal Sci. 2010; 1: 47-49.

[24] Pappano AJ. Basic and Clinical Pharmacology by Katzung BG. In: Cholinoceptor-Activating and Cholinesterase-Inhibiting Drugs, 2007.

[25] Priyadarsini R, Tamilarasi K, Karunambigai A, Gayathri DS. Antioxidant potential of the leaves and roots of Solanum surattense. Plant Arch. 2010; 10: 815-18.

[26] Shahiladevi S, Jayanthi G, Jegadeesan M. Preliminary phytochemical studies on Solanum surattenseburm. f. Seeds, Ancient Science of Life. 2006; 25: 59-64.

[27] Van-Rossum JM. Cumulative concentration-response curves Techniques for making concentration response curves in isolated organs and evaluation of drug parameters. Archives international de pharmacodynamic \& therapies. 1963; 143: 229-33.

[28] Weissenberg M. Isolation of solasodine and other steroidal alkaloids and sapogenins by direct hydrolysis - extraction of Solanum plants or glycosides. Phytochemistry. 2001; 58: 501-08. https://doi.org/10.1016/S0031-9422(01)00185-6 